\title{
Delayed metamorphosis in decapod crustaceans: evidence and consequences
}

\author{
Retraso de la metamorfosis en crustáceos decápodos: evidencias y consecuencias
}

\author{
PAULINA GEBAUER ${ }^{1}$, KURT PASCHKE ${ }^{1} \&$ KLAUS ANGER ${ }^{2}$
}

${ }^{1}$ Facultad de Pesquerías y Oceanografía, Universidad Austral de Chile, Casilla 1327, Puerto Montt, Chile; e-mail: pgebauer@uach.cl

${ }^{2}$ Biologische Anstalt Helgoland, Stifftung Alfred-Wegener-Institut für Polar- und Meeresforschung, 27498 Helgoland, Germany

\begin{abstract}
Most marine invertebrate species exhibit a complex life cycle including a planktonic larval phase and a benthic juvenileadult phase. Metamorphosis and settlement are the links between these phases of development. In many species, metamorphosis is triggered by specific chemical and/or physical cues, mainly associated with the adult habitat. In the absence of such cues, competent larvae can delay their metamorphosis by a few days to several months. Most investigations on the delay of metamorphosis have been realised on sessile or sedentary species. In relation to mobile decapod crustaceans, the number of such studies is low, probably because the members of this group retain their mobility after metamorphosis, and hence, may depend less on enviromental cues for the induction of settlement and metamorphosis. Nevertheless, the larvae of some decapod species have been shown to depend on metamorphosis-stimulating cues. These include special types of substrates, physical or chemical traits of particular (e.g., estuarine) water bodies, as well as odors from conspecific or congeneric adults. The capacity for delay is, in the decapod species studied so far, limited and may normally end with spontaneous metamorphosis. An extended time of larval development presents the advantage of enhancing the probability for locating a suitable habitat, but it may imply, as a disadvantage, a reduction of juvenile growth or survival and a prolonged development time preceding benthic life. This paper reviews the available evidence for delayed metamorphosis in decapod crustaceans, indentifed cues, the importance of larval age at the time of contact with a cue, and costs of delayed metamorphosis. Additionally, we propose new frontiers for future investigations on delayed metamorphosis in decapod crustaceans, including the molecular identification of chemical cues, the identification of the stage(s) of the moulting cycle that is or are sensitive to such cues, the study of hormonally mediated effects on the moulting cycle, the quantification of energetic or other costs of delayed metamorphosis, and the analysis of relationships between the effectiveness of adult odors and phylogenetic proximity of larvae and adults.
\end{abstract}

Key words: delayed metamorphosis, Crustacea, larvae.

\section{RESUMEN}

Numerosos invertebrados marinos tienen un ciclo de vida bifásico, el cual incluye una fase larval planctónica y una juveniladulta bentónica. La metamorfosis y asentamiento son los eslabones entre estas dos fases del desarrollo. La metamorfosis en muchas especies es gatillada por estímulos físicos y/o químicos, generalmente relacionados con el hábitat parental. Las larvas competentes, en ausencia de estos inductores, pueden retardar la metamorfosis desde algunos días hasta meses. La mayoría de las investigaciones sobre retraso de la metamorfosis han sido realizadas en especies sedentarias o sésiles. En crustáceos decápodos (móviles) la cantidad de estudios relacionados con la inducción del asentamiento y metamorfosis por estímulos específicos y la capacidad de retraso de la metamorfosis es mucho menor, y se podría deber a que este grupo no pierde su capacidad de movimiento post-metamorfosis, por lo cual el hábitat de asentamiento y metamorfosis podría no ser tan crucial para este grupo como en las especies sésiles o sedentarias. Sin embargo, en algunas especies de crustáceos decápodos se ha reportado la importancia de la presencia de estímulos específicos para el asentamiento y metamorfosis y la flexibilidad en el momento de la metamorfosis en ausencia de tales estímulos. En general, los estímulos identificados que gatillan la metamorfosis son algunos tipos de substratos, la presencia de adultos conespecíficos o congenéricos. La capacidad de retraso de la metamorfosis en las especies de decápodos estudiadas es limitada y generalmente finaliza con una metamorfosis espontánea. La prolongación del tiempo de desarrollo presenta ventajas ya que aumenta la probabilidad de localizar un hábitat favorable y desventajas al aumentar la mortalidad, el tiempo de desarrollo y reducir el tamaño de los estadios bentónicos. El objetivo del presente trabajo es presentar las evidencias disponibles sobre el retraso de la metamorfosis, los estímulos identificados, la importancia de la edad de la larva al momento de contacto con el estímulo inductor y los costos del retraso de la metamorfosis en crustáceos decápodos. Así como los tópicos de investigación importantes de abordar en el futuro como: identificación molecular del estímulo, etapa del ciclo de la muda donde actúa y como actúa el estímulo, evaluación de los costos asociados al retraso de la metamorfosis, efectividad del estímulo con relación a distancias filogenéticas y dependencia de especies con estrategia exportiva a estímulos relacionados con el hábitat parental.

Palabras clave: retraso de la metamorfosis, crustáceos, larvas. 


\section{INTRODUCTION}

Within the life cycle of many marine organisms with a pelagic larval phase one of the most critical moments is the transition to the benthic habitat. Two processes are involved in this phase, settlement and metamorphosis.

In many larvae, these processes are triggered by specific chemical and/or physical cues associated with the adult habitat (Crisp 1974, Hadfield 1978, Burke 1983, Pechenik 1990, Forward et al. 1997, Lau \& Qian 2001, Gebauer et al. 2002). The absence of such cues at the time when larvae are competent to metamorphose may cause a developmental delay of several hours to months (Pechenik 1990) before being concluded by spontaneous metamorphosis or death, depending of the species (Zimmerman \& Pechenik 1991, Zalow \& Benayahu 1996, Gebauer et al. 1998). Flexibility in the timing of metamorphosis has been considered as a selective advantage, because it should enhance the probability of locating a habitat suitable for juvenile and adult survival (Thorson 1950, Crisp 1974, Obrebski 1979, Morgan 1995). However, postponing metamorphosis might also carry costs, if the larvae with prolonged development time produce juveniles that exhibit high mortality and/or reduced size (Pechenik \& Cerulli 1991, Pechenik et al. 1993, Gebauer et al. 1999, Maldonado \& Young 1999, Pechenik \& Rice 2001, Phillips 2002).

The goal of this work is to review available evidence of delayed metamorphosis in decapod crustaceans. We concentrate specifically on (1) cues that influence the late phase of larval development of decapod crustaceans (metamorphosis and settlement) (2) the time of metamorphic competence, and (3) the costs of an extended larval phase (delayed metamorphosis). Finally, we suggest some new frontiers for future investigations.

\section{CUES FOR METAMORPHOSIS IN DECAPOD CRUSTACEANS}

Studies on the dependence of metamorphosis on exogenous cues in mobile species such as decapod crustaceans are scarce compared to the number of studies that have been conducted on sessile species. This imbalance is probably due to the fact that the former do not lose their mobility following metamorphosis and thus maintain the capacity to find habitats with better conditions than those encountered during the initial place of settlement and metamorphosis.

During recent years, increasing evidence has accumulated demonstrating flexibility also in the timing of metamorphosis in larvae of various mobile species, depending on the presence or absence of specific cues, similar to what is known from sessile species (McCormick 1999).

In larvae of decapod crustaceans, several cues have been identified to serve as inducers of metamorphosis. For example, the type and size of available snail shells are important cues for metamorphosis in some species of hermit crabs (Harms 1992, Harvey 1996, Brodie 1999). Different substrata which represent characteristics of the adult habitat are effective cues inducing metamorphosis in larvae of Homarus americanus (Botero \& Atema 1982), Uca pugilator and U. pugnax (Christy 1989, O'Connor 1991, O'Connor \& Judge 1997), Callinectes sapidus (Forward et al. 1994), Panopeus herbstii (Dittel et al. 1996, Weber \& Epifanio 1996), and Chasmagnathus granulata (Gebauer et al. 1998) (see Table 1). In estuarine waters, further inducers such as decreased salinity and the presence of humic acids may accelerate metamorphosis in larvae of decapod species (Wolcott \& DeVries 1994, Forward et al. 1997). Odors secreted by conspecific adults were observed to trigger metamorphosis in the megalopae of Petrolisthes spp. (Jensen 1991), U. pugilator and U. pugnax (O'Connor 1991, O'Connor \& Gregg 1998), Pagurus maclaughlinae and Paguristes tortugae (Harvey 1996), C. granulata (Gebauer et al. 1998), P. herbstii (Rodríguez \& Epifanio 2000), and Sesarma curacaoense (Gebauer et al. 2002) (Table 1).

Larvae do not only respond to a single specific cue but also to combinations of various stimuli. In C. granulata, for example, the presence of conspecific adults in combination with a muddy substratum (typical sediment in habitats where this species lives) was found to induce metamorphosis faster than each isolated stimulus (Gebauer et al. 1998). Similar results has been reported for megalopae of $U$. pugilator (O'Connor 1991; Table 1). One conceivable explanation for these results could be an accumulation of substances secreted by the adults on the substratum, producing a higher concentration of this cue and hence a stronger effect of the cues on the metamorphosis of megalopae.

Recent studies demonstrated that megalopae of different species may respond not only to odors secreted by conspecific adults, but also to those from congeners. Gebauer et al. (2002) showed that megalopae of Sesarma curacaoense respond to a substance secreted by both conspecific and and congeneric adults ( $S$. rectum), while substances secreted by other (phylogenetically more distant) Grapsidae had no such effects. A similar pattern has been reported from $P$. herbstii, where 
the time to metamorphosis was reduced when megalopae were in contact with exudates produced by members of their own species or by Dyspanopeus sayi, but no effect was observed when megalopae received stimuli from adult $U$. pugnax (Rodríguez \& Epifanio 2000). These results show than the metamorphosis-stimulating effect tends to decrease with increasing phylogenetic distance. However, this may not be a general pattern, as the megalopae of Petrolisthes cinctipes did not show gregarious settlement in response to adults of the congeneric species $P$. eriomerus (Jensen 1989). Similarly, in an investigation conducted by O'Connor \& Gregg (1998), megalopae of Uca pugnax maintained with adult water of $U$. minax showed no reduced development time. Thus, cross-species activities of exudates from closely related crab species is not universal and might depend on whether particular species live sympatrically or not. A cross effect of substances secreted by species that share the same habitat could present a disadvantage, as it may increase the interspecific competition for benthic resources. Future studies are required to test this prediction and establish the particular conditions where congeneric cues can or can not induce metamorphosis.

\section{METAMORPHIC COMPETENCE}

During the larval period it is, in general, possible to distinguish two different phases: (1) a precompetence phase, where the larva has no capacity to metamorphose and principally functions for dispersal and growth in the plankton, (2) the final phase of competence in which the larva is physiologically and morphologically prepared

TABLE 1

Summary of cues for metamorphosis in different species of Decapod Crustaceans

Resumen de inductores de la metamorfosis en diferentes especies de crustáceos decápodos

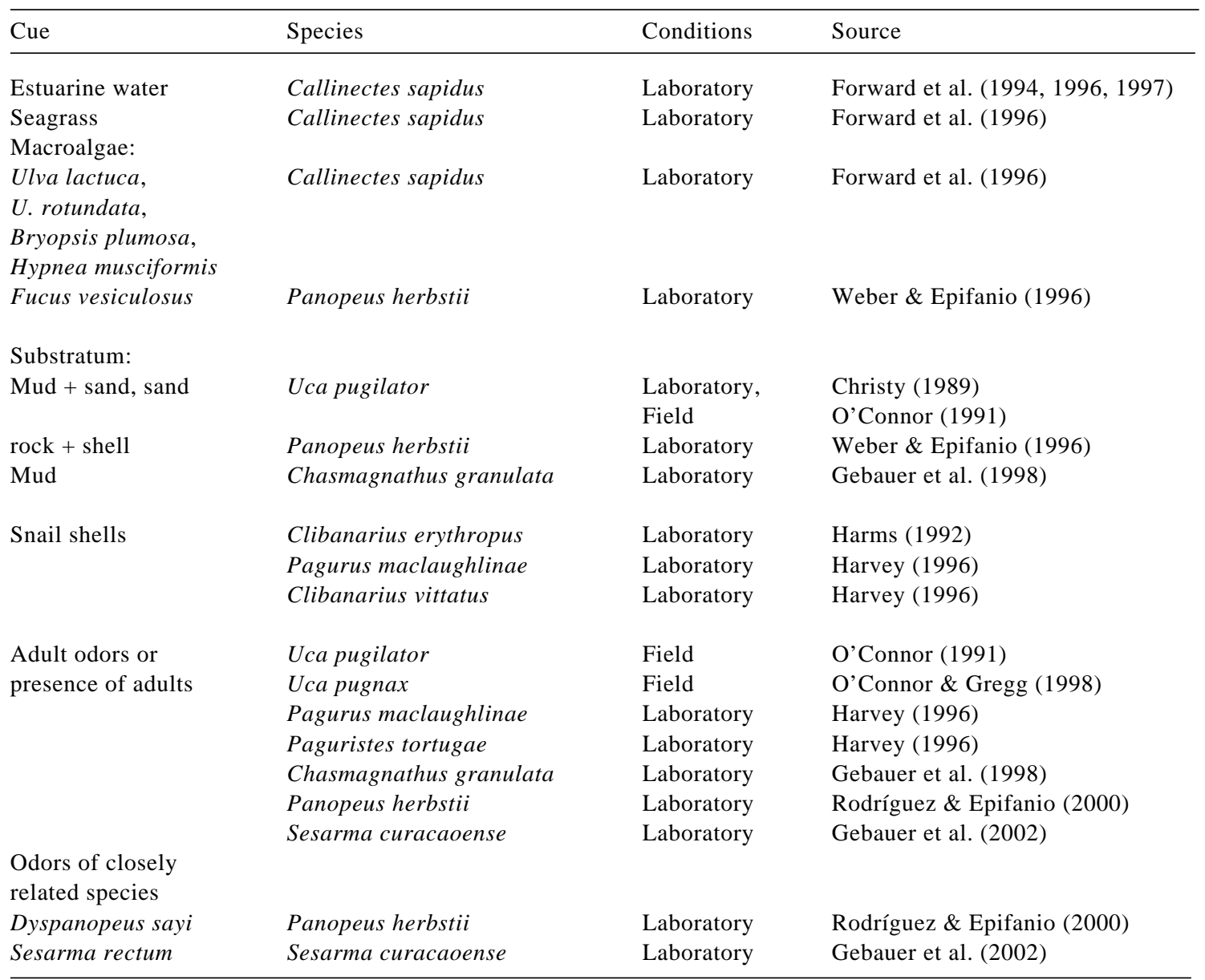


to respond to cues that induce metamorphosis (Crisp 1974, Pechenik 1985, 1999, Pawlik 1992, Avila 1998, Bryan et al. 1998). The onset of metamorphic competence can be identified by triggering metamorphosis with an identified cue after previous absence of morphological or behavioural patterns related to metamorphosis (Pechenik 1984, Pechenik \& Heyman 1987, Miller \& Hadfield 1986, Pechenik \& Qian 1998).

Experiments specifically designed to determine the earliest moment and the length of time of contact with a stimulus required to stimulate a positive larval response are scarce. In most investigations, the contact with the stimulus occurs at the beginning of the megalopa stage. The suitable moment and the length of the period during which the megalopae should be in contact with the cue have been demonstrated for Sesarma curacaoense and Chasmagnathus granulata. The megalopae of these species were experimentally placed into contact with the cue (conspecific adult odors) for differential periods of time during their moulting cycle. The results of these investigations demonstrated that the megalopae of $S$. curacaoense had latest to come into contact with the cue when about $65 \%$ of their moulting cycle had elapsed, and this contact had to last for approximately one day. In $C$. granulata, this event should latest occur after $32-53 \%$ of the time of megalopal development and for a duration of about five days (Gebauer unpubl.). Later or shorter contacts with the cue did not affect the timing of metamorphosis, so that the megalopae metamorphosed at the same age as control larvae that never were in contact with the cue. A similar pattern was found in Uca pugnax, where the appropriate moment for megalopae to receive the metamorphic stimulus was observed after approximately at $67 \%$ of their moulting cycle (O'Connor \& Gregg 1998).

Although it is not possible to generalise the few available observations on the exact moment at which larvae become receptive to a metamorphic cue, some tendencies can be identified for the three species studied so far: in all cases, the megalopae appear to be most receptive to such cues during the intermoult, $\mathrm{C}$ (after 30-50\% of development), and premoult period, $\mathrm{D}_{0}$ (after 45 $76 \%$ of development), when an increase in the secretion of moulting hormone occurs (Spindler \& Anger 1986, Anger 1987, 2001). The cue might thus aid to the increase in hormonal (ecdysteroid) levels and/or to the synchronisation of the moult process. Contact of the megalopa with cues in a late phase of the moulting cycle $\left(\mathrm{D}_{2}-\mathrm{D}_{4}\right.$ premoult) had, in the species studied, no effect on the moment of metamorphosis, which might be explained by a determination of the developmental program before this period. This program seems to be largely independent of extrinsic factors, as suggested by Anger (2001) who discussed the absence of effects of starvation or the inability to regenerate mutilated limbs during the late premoult period.

\section{COSTS OF DELAYED METAMORPHOSIS}

Delayed metamorphosis has been considered as a selective advantage for species that present this capacity, because it should enhance the probability of locating a suitable habitat for their benthic phase (e.g., Thorson 1950). However, delayed metamorphosis might also produce costs such as decreased juvenile survival or size. In species with lecithotrophic (i.e. non-feeding) larvae, generally, delayed metamorphosis affects the postmetamorphic stages due to an extended period of metabolic energy losses (see Pechenik et al. 1998, Pechenik 1999 for review). In planktotrophic larvae, in contrast, a prolonged larval period may not normally affect postsettlement fitness (Pechenik \& Eyster 1989), because such larvae continue feeding i.e., they do not depend on internal energy reserves. If such larvae are nutritionally stressed during their previous development, however, postmetamorphic costs can also occur (Pechenik et al. 1996, Phillips 2002).

In decapod crustaceans, the consequences of delayed metamorphosis have been little studied and there is no consistent pattern (Hunt \& Scheibling 1997). Costs of delayed metamorphosis in the form of reduced growth rates of first juveniles have been observed in a hermit crab (Clibanarius longitarsus) (Harvey 1992). Enhanced mortality and reduction of size after a significant prolongation of the larval phase in absence of metamorphosis-stimulating cues have been demonstrated also in the first benthic stage of Chasmagnathus granulata. A possible explanation for such costs may be in an additional utilization of internal reserves, due to a substantial reduction of the ingestion rate during the latest phase of the megalopal moulting cycle, even under constant and optimal feeding conditions (Anger 1991, 2001). Due to their smaller initial size, juveniles originating from megalopae with delayed metamorphosis might be more vulnerable also to benthic predation, especially to cannibalism within or between conspecific cohorts of recruits (Eggleston \& Amstrong 1995, Hunt \& Scheibling 1997, Moksness et al. 1998, Luppi et al. 2001). In general, intraspecific postsettlement predation is considered as one of 
the potential key factors regulating population density and structure in benthic decapods (e.g., Fernández et al. 1993, Hines \& Ruiz 1995, Lovrich \& Sainte-Marie 1997, Moksness et al. 1997, Luppi et al. 2002). In addition, smaller juveniles are probably also comparatively weak competitors for food and refuge, which should further reduce their probability of survival and growth in natural habitats (Hines 1986).

\section{CONCLUSIONS}

The ability to delay metamorphosis is not an exclusive characteristic of sessile or sedentary species. Megalopae of some mobile decapods have the capacity to respond to specific cues of the adult habitat, and to adjust the timing of settlement and metamorphosis correspondingly. The length of this possible delay is, in general, shorter than in sessile species; it may be concluded by "spontaneous" metamorphosis if no appropriate cues are provided.

These conclusions open several important frontiers for future investigations, for instance the chemical identification and specificity of cues involved in settlement and metamorphosis, or studies of the performance of juveniles and adults in relation to conditions experienced during the larval phase.

Further it should be examined during which stages of the moulting cycle and how metamorphosis-stimulating cues may act during the different phases of the moulting cycle, addressing also the question whether they enhance and/or synchronise hormonal processes.

It is further recommended that we direct more attention to fully marine species, since the available information is centered on estuarine species with a larval export strategy. Additional questions emerge also in the latter category, for example if the larvae of all -or most-species with an export strategy have the capacity to recognize estuarine characteristics as indicators of an adequate habitat likely to promote successful settlement and metamorphosis.

The potential costs linked to periods of delayed metamorphosis lead to some of the most interesting questions in this context. Is reduced size and low survival rate of juveniles originating from megalopae that have delayed metamorphosis a consistent pattern in decapod crustaceans? Are those juveniles weak competitors and/or are they particularly vulnerable to benthic predation or vulnerable for a longer period of time, so that their chances of successful growth and reproduction may be significantly reduced? If those costs indeed are a common consequence of delayed metamorphosis in decapod crustaceans, the causes of these costs should be determined. Are such costs consequences of prolonging the moult stage causing a reduced ingestion of food and an increasing utilization of internal reserves, or are there other underlying causes? The answers to these questions will help to understand the many subtle factors influencing the recruitment success and population dynamics of marine crustaceans.

Clearly, this brief review demonstrates that in crustaceans, as in other marine invertebrates, there are close links between the planktonic larval and the subsequent benthic phase of the life cycle (for a recent discussion, see Giménez 2003, Giménez \& Anger 2003). Emphasizing those links, Pechenik et al. (1998) stated that the metamorphosis is not a new beginning, but rather a continuation within the life history.

\section{ACKNOWLEDGEMENTS}

The first author acknowledges a research grant from the Biologische Anstalt Helgoland, Germany, a grant (DID D2001-12) from the Universidad Austral de Chile, and a grant from CONICYT, Chile; the second author acknowledges a grant (DID S2001-59) from the Universidad Austral de Chile.

\section{LITERATURE CITED}

ANGER K (1987) The $\mathrm{D}_{0}$ threshold: a critical point in the larval development of decapod crustaceans. Journal of Experimental Marine Biology and Ecology 108: 15-30.

ANGER K (1991) Development changes in the bioenergetics of decapod larvae. Memorial Queensland $\mathrm{Mu}-$ seum 31: 289-308.

ANGER K (2001) The biology of Decapod Crustacean larvae. In: Vonk R (ed) Crustacean issues 14. A.A. Balkema Publishers, Lisse, The Netherlands. 405 pp.

ÁVILA C (1998) Competence and metamorphosis in the longterm planktonic larvae of the nudibranch mollusc Hermissenda crassicornis (Eschscholtz, 1831). Journal of Experimental Marine Biology and Ecology 231: 81-117.

BOTERO L \& J ATEMA (1982) Behavior and substrate selection during larval settling in the lobster Homarus americanus. Journal of Crustacean Biology 2: 59-69.

BRODIE RJ (1999) Ontogeny of shell-related behaviors and transition to land in the terrestrial hermit crab Coenobita compressus H. Milne Edwards. Journal of Experimental Marine Biology and Ecology 241: 6780 . 
BRYAN PJ, JL KRIEDER \& P-Y QIAN (1998) Settlement of the serpulid polychaete Hydroides elegans (Haswell) on the arborescent bryozoan Bugula neritina (L): evidence of the chemically mediated relationship. Journal of Experimental Marine Biology and Ecology 220: 171-190.

BURKE RD (1983) The induction of metamorphosis of marine invertebrate larvae: stimulus and response. Canadian Journal Zoology 61: 1701-1719.

CHRISTY JH (1989) Rapid development of megalopae of the fiddler crab Uca pugilator reared over sediment: implications for models of larval recruitment. Marine Ecology Progress Series 57: 259-265.

CRISP DJ (1974) Factors influencing the settlement of marine invertebrate larvae. In. Grant PT \& AM Mackie (eds) Chemoreception in marine organisms: 177-265 Academic Press, London, United Kingdom.

DITTEL A, CE EPIFANIO \& C NATUNEWICZ (1996) Predation on mud crab megalopae, Panopeus herbstii H. Milne Edwards: effect of habitat complexity, predator species and postlarval densities. Journal of Experimental Marine Biology and Ecology 199: 191202.

EGGLESTON DB \& DA ARMSTRONG (1995) Pre- and post-settlement determinants of estuarine dungeness crab recruitment. Ecological Monographs 65: 193216.

FERNANDEZ M, O IRIBARNE \& D ARMSTRONG (1993) Habitat selection by young-of-the-year dungeness crab Cancer magister and predation risk in intertidal habitats. Marine Ecology Progress Series 92: 171-177.

FORWARD RB, MC DE VRIES, D RITTSCHOF, DAZ FRANKEL, JP BISCHOFF, CM FISHER \& JM WELCH (1996) Effects of environmental cues on metamorphosis of the blue crab Callinectes sapidus. Marine Ecology Progress Series 131: 165-177.

FORWARD RB, DAZ FRANKEL \& D RITTSCHOF (1994) Molting of megalopae from the blue crab Callinectes sapidus: effects of offshore and estuarine cues. Marine Ecology Progress Series 113: 55-59.

FORWARD RB, RA TANKERSLEY, D BLONDEL \& D RITTSCHOF (1997) Metamorphosis of the blue crab Callinectes sapidus: Effects of humic acids and ammonium. Marine Ecology Progress Series 157: 277286.

GEBAUER P, K PASCHKE \& K ANGER (1999) Costs of delayed metamorphosis: reduced growth and survival early juveniles of an estuarine grapsid crab, Chasmagnathus granulata. Journal of Experimental Marine Biology and Ecology 238: 271-281.

GEBAUER P, K PASCHKE \& K ANGER (2002) Metamorphosis in a semiterrestrial crab, Sesarma curacaoense: intra-and interspecific settlement cues from adult odors. Journal of Experimental Marine Biology and Ecology 268: 1-12.

GEBAUER P, I WALTER \& K ANGER (1998) Effects of substratum and conspecific adults on the metamorphosis of Chasmagnathus granulata (Dana) (Decapoda: Grapsidae) megalopae. Journal of Experimental Marine Biology and Ecology 223: 185-198.

GIMÉNEZ L (2003) Potential effects of physiological plastic responses to salinity on population networks of the estuarine crab Chasmagnathus granulata. Helgoland Marine Research 56: 265-273.
GIMÉNEZ L \& K ANGER (2003) Larval performance in an estuarine crab, Chasmagnathus granulata, is a consequence of both larval and embryonic experience. Marine Ecology Progress Series 249: 251-264.

HADFIELD MG (1978) Metamorphosis in marine molluscan larvae: an analysis of stimulus and response. In: Chia FS \& ME Rice (eds) Settlement and metamorphosis of marine invertebrate larvae: 165-175. Elsevier, New York, New York, USA.

HARMS J (1992) Larval development and delayed metamorphosis in the hermit crab Clibanarius erythropus (Latreille) (Crustacea, Diogenidae). Journal of Experimental Marine Biology and Ecology 156: 151-160.

HARVEY AW (1992) Costs and benefits of delayed metamorphosis in the hermit crab Clibanarius longitarsus. American Zoologist 32:114.

HARVEY AW (1996) Delayed metamorphosis in Florida hermit crabs: multiple cues constraints (Crustacea: Decapoda: Paguridae and Diogenidae). Marine Ecology Progress Series 141: 27-36.

HINES AH \& GM RUIZ (1995) Temporal variation in juvenile blue crab mortality: nearshore shallows and cannibalism in Chesapeake Bay. Bulletin of Marine Science 57: 884-901.

HUNT HL \& RE SCHEIBLING (1997) Role of early postsettlement mortality in recruitment of benthic marine invertebrates. Marine Ecology Progress Series 155: 269-301.

JENSEN GC (1989) Gregarious settlement by megalopae of the crabs Petrolisthes cinctipes (Randall) and $P$. eriomerus Stimpson. Journal of Experimental Marine Biology and Ecology 131: 223-231.

JENSEN GC (1991) Competency, settling behavior, and postsettlement aggregation by porcelain crab megalopae (Anomura: Porcellanidae). Journal of Experimental Marine Biology and Ecology 153: 49-61.

LAU SCK \& P-Y QIAN (2001) Larval settlement in the serpulid polychaeta Hydroides elegans, in response to bacterial films: an investigation of the nature of putative larval settlement cue. Marine Biology 138: 321-328.

LOVRICH GA \& B SAINTE-MARIE (1997) Cannibalism in the snow crab, Chionoecetes opilio (O. Fabricius) (Brachyura: Majidae), and its potential importance to recruitment. Journal of Experimental Marine Biology and Ecology 211: 225-245.

LUPPI TA, ED SPIVAK \& K ANGER (2001) Experimental studies on predation and cannibalism of the settlers of Chasmagnathus granulata and Cyrtograpsus angulatus (Brachyura: Grapsidae). Journal of Experimental Marine Biology and Ecology 265: 29-48.

LUPPI TA, ED SPIVAK, K ANGER \& JL VALERO (2002) Patterns and processes of Chasmagnathus granulata and Cyrtograpsus angulatus (Brachyura: Grapsidae) recruitment in Mar Chiquita coastal lagoon, Argentina. Estuarine, Coastal and Shelf Science 55: 287-297.

MALDONADO M \& MC YOUNG (1999) Effects of the duration of larval life on postlarval stages of the demosponge Signadocia caerulea. Journal of Experimental Marine Biology and Ecology 232: 9-21.

McCORMICK MI (1999) Delayed metamorphosis of a tropical reef fish (Acanthurus triostegus): a field experiment. Marine Ecology Progress Series 176: 25-38. 
MILLER SE \& MG HADFIELD (1986) Ontogeny of phototaxis and metamorphic competence in larvae of the nudibranch Phestilla sibogae Bergh (Gastropoda: Opisthobranchia). Journal of Experimental Marine Biology and Ecology 97: 95-112.

MOKSNESS PO, RN LIPCIUS, L PHIL \& J VAN MONTFRANS (1997) Cannibal-prey dynamics in young juveniles and postlarvae of the blue crab. Journal of Experimental Marine Biology and Ecology 215: 157-187.

MOKSNESS PO, L PHIL \& J VAN MONTFRANS (1998) Predation on postlarvae and juveniles of the crab Carcinus maenas: importance of shelter, size and cannibalism. Marine Ecology Progress Series 166: 211-225.

MORGAN SG (1995) Life and death in the plankton: larval mortality and adaptation. In: McEdward L (ed) Ecology of marine invertebrate larvae 279-321. CRC Press, Boca Raton, Florida, USA.

OBREBSKI S (1979) Larval colonizing strategies in marine benthic invertebrates. Marine Ecology Progress Series 1: 293-300.

O'CONNOR N (1991) Flexibility in timing of metamorphic molt by fiddler crab megalopae Uca pugilator. Marine Ecology Progress Series 68: 243-247.

O'CONNOR N \& ML JUDGE (1997) Flexibility in timing of molting of fiddler crab megalopae: evidence from in situ manipulation of cues. Marine Ecology Progress Series 146: 55-60.

O'CONNOR N \& AS GREGG (1998) Influence of potential habitat cues on duration of megalopal stage of the fiddler crab Uca pugnax. Journal of Crustacean Biology 18: 700-709.

PAWLIK JR (1992) Chemical ecology of the settlement of benthic marine invertebrates. Oceanography Marine Biology Annual Review 30: 273-335.

PECHENIK JA (1984) The relationship between temperature, growth rate, and duration of larval life for larvae of the gastropod Crepidula fornicata (L.). Journal of Experimental Marine Biology and Ecology 74: 241-257.

PECHENIK JA (1985) Delayed metamorphosis of marine molluscan larvae: current status and directions for future research. American Malacological Bulletin 1: 85-91.

PECHENIK JA (1990) Delayed of metamorphosis by larvae of benthic marine invertebrates: does it occur? is there a price to pay? Ophelia 32: 63-94.

PECHENIK JA (1999) On the advantages and disadvantages of larval stages in benthic marine invertebrate life cycles. Marine Ecology Progress Series 177: 269-297.

PECHENIK JA \& TR CERULLI (1991) Influence of delayed metamorphosis on survival, growth, and reproduction of the marine polychaete Capitella sp. I. Journal of Experimental Marine Biology and Ecology 151: 17-27.

PECHENIK JA \& S EYSTER (1989) Influence of delayed metamorphosis on the growth and metabolism of young Crepidula fornicata (Gastropoda) juveniles. Biological Bulletin 176: 14-24.
PECHENIK JA \& WD HEYMAN (1987) Using KCl to determine size at competence for larvae of marine gastropod Crepidula fornicata (L.). Journal of Experimental Marine Biology and Ecology 112: 27-38.

PECHENIK JA \& P-Y QIAN (1998) Onset and maintenance of metamorphic competence in the polychaete Hydroides elegans Haswell in response to three chemical cues. Journal of Experimental Marine Biology and Ecology 226: 51-74.

PECHENIK JA \& ME RICE (2001) Influence of delayed metamorphosis on postsettlement survival and growth in the sipunculan Apionsoma misakianum. Invertebrate Biology 120: 50-57.

PECHENIK JA, MS ESTRELLA \& K HAMMER (1996) Food limitation stimulates metamorphosis of competent larvae and alters postmetamorphic growth rate in the marine prosobranch gastropod Crepidula fornicata. Marine Biology 127: 267-275.

PECHENIK JA, D RITTSCHOF \& AR SCHMIDT (1993) Influence of delayed metamorphosis on survival and growth of juvenile barnacles Balanus amphitrite. Marine Biology 115: 14-24.

PECHENIK JA, DE WENDT \& JN JARRET (1998) Metamorphosis is not a new beginning, Larval experience influences juvenile performence. Bioscience 48: 901 910.

PHILLIPS NE (2002) Effects of nutrition-mediated larval condition on juvenile performance in a marine mussel. Ecology 83: 2562-2574.

RODRÍGUEZ RA \& CE EPIFANIO (2000) Multiple cues for induction of metamorphosis in larvae of the common mud crab Panopeus herbstii. Marine Ecology Progress Series 195: 221-229.

SPINDLER KD \& K ANGER (1986) Ecdysteroid levels during the larval development of the spider crab Hyas araneus. General and Comparative Endocrinology 64: $122-128$.

THORSON G (1950) Reproductive and larval ecology of marine bottom invertebrates. Biological Reviews 25: $1-45$.

WEBER JC \& CE EPIFANIO (1996) Response of mud crab (Panopeus herbstii) megalopae to cues from adult habitat. Marine Biology 126: 655-661.

WOLCOTT DL \& MC DEVRIES (1994) Offshore megalopae of Callinectes sapidus: depth of collection, molt stage and response to estuarine cues. Marine Ecology Progress Series 109: 157-163.

ZALOW RBD \& Y BENAYAHU (1996) Longevity, competence and energetic content in planulae of the soft coral Heteroxenia fuscescens. Journal of Experimental Marine Biology and Ecology 206: 55-68.

ZIMMERMAN KM \& JA PECHENIK (1991) How do temperature and salinity effect relative rates growth, morphological differentiation, and time to metamorphic competence in larvae of marine gastropod Crepidula plana? Biological Bulletin 180: 372-386. 